\title{
PENGARUH BIAYA OVERHEAD, BAGI HASIL DANA PIHAK KETIGA, DAN PROFIT TARGET TERHADAP MARGIN PEMBIAYAAN MURABAHAH
} ( Studi Kasus Pada PT. Bank Muamalat Tbk Cabang Jambi )

\author{
Oleh : \\ Enggar Diah Puspa Arum \\ (Dosen Fakultas Ekonomi Universitas Jambi)
}

\begin{abstract}
Abstrak
Tujuan dari penelitian ini adalah untuk mengetahui pengaruh biaya overhead, porsi bagi hasil dana pihak ketiga dan profit target terhadap margin pembiayaan murabahah pada PT. Bank Muamalat Indonesia Tbk Cabang Jambi. Sistem perbankan yang mengharamkan bentuk riba dalam segala aktivitasnya membuat bank syariah menerapkan sistem yang berbeda dalam semua produknya, termasuk pembiayaan murabahah. Penelitian dilakukan terhadap pembiayaan murabahah selama bulan April 2009 sampai dengan Maret 2010 dengan menggunakan model regresi linier berganda untuk melihat pengaruh masing-masing variabel bebas terhadap variabel terikat. Hasil penelitian ini menunjukkan bahwa biaya overhead berpengaruh signifikan terhadap margin pembiayaan murabahah, sedangkan porsi bagi hasil dana pihak ketiga dan profit target tidak berpengaruh signifikan terhadap margin pembiayaan murabahah.
\end{abstract}

Kata Kunci: Margin pembiayaan murabahah, biaya overhead, porsi bagi hasil dana pihak ketiga, profit target.

\section{Latar Belakang}

Sistem ekonomi Syariah, atau adakalanya disebut "ekonomi Islam", semakin populer bukan hanya di negara-negara Islam tapi bahkan juga di negara-negara barat. Hal ini ditandai dengan makin banyaknya beroperasi bank-bank yang menerapkan konsep syari'ah (Anonim, 2005). Krisis global di Amerika Serikat, yang berdampak luas pada terpuruknya perekonomian dunia tahun 2008, menjadi penyebab utama beralihnya konsep ekonomi kapitalis ke konsep ekonomi syariah, dengan produk-produk perbankannya, yang mengutamakan filosofi kemitraan dan kebersamaan.

Perbankan syariah sendiri menunjukkan ketangguhannya pada medio awal krisis moneter yang menimpa Indonesia pada 1997 hingga 1998 yang merupakan masa terberat bagi seluruh sistem perekonomian Indonesia termasuk lembaga keuangan dan perbankan. Tingginya tingkat suku bunga telah mengakibatkan tingginya biaya modal bagi sektor usaha yang pada akhirnya mengakibatkan merosotnya kemampuan sektor usaha produksi. Pada masa krisis tersebut jajaran perbankan konvensional berusaha untuk terus menarik dana-dana masyarakat dengan memberikan imbalan yang tinggi kepada para deposan mereka sesuai dengan tingkat suku bunga pasar. Akan tetapi, hal ini menimbulkan dampak negatif kepada sektor riil dan industri karena perbankan konvensional menghindari untuk memberikan kredit dengan bunga rendah kepada sektor tersebut. Ini mengakibatkan industri dan sektor produksi mengalami penurunan kinerja mereka secara signifikan dan mengakibatkan rendahnya kemampuan daya saing usaha pada sektor produksi. Dalam masa tersebut justru perbankan syariah dapat menunjukkan kinerja yang relatif baik di bandingkan dengan lembaga perbankan konvensional. Hal ini dapat dilihat dari relatif lebih rendahnya penyaluran pembiayaan yang bermasalah (non performing financing) pada bank syariah dan tidak terjadinya negative spread dalam kegiatan operasionalnya. Hal tersebut dapat dipahami mengingat tingkat pengembalian pada bank syariah tidak mengacu pada tingkat suku bunga tabungan dan deposito yang telah 
ditetapkan oleh Bank Indonesia karena perbankan syariah tidak menganut sistem bunga dan pada akhirnya dapat menyediakan dana investasi dengan biaya yang relatif lebih rendah kepada masyarakat (Heykal: 2005).

Perbankan syariah menawarkan produk-produk perbankan yang sesuai dengan skim fiqih Islam. Salah satu produknya adalah murabahah yang merupakan pembiayaan dengan mengambil bentuk transaksi jual beli antara pihak bank dengan nasabah dengan cara pembayaran angsuran. Dalam perjanjian murabahah, bank membiayai pembelian barang atau asset yang dibutuhkan oleh nasabahnya dengan membeli barang itu dari pemasok barang dan kemudian menjualnya kepada nasabah tersebut dengan menambahkan suatu margin keuntungan.

Dari data statistik perkembangan perbankan syariah, terlihat bahwa bentuk pembiayaan murabahah memegang peranan penting yang memberikan porsi terbesar dalam penyaluran dana. Hal ini dapat karena murabahah adalah pembiayaan investasi jangka pendek, dan dibandingkan dengan sistem profit and loss Sharing (PLS) cukup memudahkan. Kemudian mark up yang ada di dalam pembiayaan murabahah dapat ditetapkan sedemikian rupa sehingga dapat memastikan bahwa bank syariah memperoleh keuntungan yang sebanding dengan bank yang berbasis bunga yang menjadi pesaing dari bank-bank syariah. Murabahah juga menjauhkan ketidakpastian yang ada pada pendapatan dari berbagai bisnis yang dijalankan dengan sistem PLS. Terakhir murabahah tidak memungkinkan bank-bank syariah untuk mencampuri manajemen bisnis, karena pihak bank bukan merupakan mitra nasabah, akan tetapi hubungan yang terjadi adalah hubungan antara kreditur dan debitur. Posisi ini jelas lebih disukai oleh pihak bank, karena pihak bank menjadi pihak yang cukup menentukan. Inilah yang membuat murabahah mengalahkan pembiayaan yang berbasis profit loss sharing (PLS) sehingga keuntungan bank yang terbesar juga berasal dari keuntungan murabahah (Heykal: 2005).

Penelitian tentang pembiayaan murabahah telah beberapa kali dilakukan, diantaranya penelitian yang dilakukan oleh Moh. Heykal dan Budi Asmita. Penelitian Moh. Heykal (2005) berjudul Analisa Faktor-Faktor yang Mempengaruhi Penetapan Margin Murabahah Untuk Produk Pembiayaan Pemilikan Rumah, Studi Kasus PT Bank Syariah Mandiri. Penelitian tersebut menginvestigasi faktor-faktor apa saja yang berpengaruh dan faktor manakah yang paling dominan dalam penetapan margin pembiayaan murabahah khususnya untuk pembiayaan pemilikan rumah di PT. Bank Syariah Mandiri. Hasil dari penelitian ini adalah faktor yang berpengaruh terhadap margin pembiayaan murabahah adalah biaya overhead, porsi bagi hasil dana pihak ketiga, profit target, dan tingkat suku bunga pinjaman bank konvensional. Sedangkan faktor yang paling dominan adalah tingkat bunga pinjaman bank konvensional.

Penelitian yang sama dilakukan juga oleh Budi Asmita (2004) dengan judul Analisis Faktor yang Mempengaruhi Margin Pembiayaan Murabahah, Studi Kasus Pada BPRS PNM Mentari. Hasil penelitiannya menunjukkan bahwa biaya overhead dan bagi hasil dana pihak ketiga berpengaruh positif secara signifikan terhadap besarnya margin pembiayaan murabahah, sedangkan profit target tidak berpengaruh secara signifikan terhadap penentuan margin pembiayaan murabahah meskipun korelasi hubungannya adalah positif.

\section{Rumusan Masalah}

Berdasarkan uraian sebelumnya maka masalah dalam penelitian ini dapat dirumuskan sebagai berikut:

1. Apakah biaya overhead, bagi hasil dana pihak ketiga dan profit target secara parsial berpengaruh terhadap margin pembiayaan murabahah yang ditetapkan oleh PT. Bank Muamalat Tbk Cabang Jambi? 
2. Apakah biaya overhead, bagi hasil dana pihak ketiga dan profit target secara simultan berpengaruh terhadap margin pembiayaan murabahah yang ditetapkan oleh PT Bank Muamalat Tbk Cabang Jambi?

\section{Kerangka Pemikiran}

Akuntansi syariah dapat diartikan sebagai proses akuntansi atas transaksitransaksi yang sesuai dengan aturan yang telah ditetapkan oleh Allah SWT. Sehingga di dalam mempelajari akuntansi syariah dibutuhkan pemahaman yang baik mengenai akuntansi sekaligus juga tentang syariah islam (Nurhayati: 2008).

Dasar hukum dalam Akuntansi Syariah bersumber dari Al Quran, Sunnah Nabawiyyah, Ijma (kesepakatan para ulama), Qiyas (persamaan suatu peristiwa tertentu, dan 'Uruf (adat kebiasaan) yang tidak bertentangan dengan Syariah Islam. Kaidah-kaidah Akuntansi Syariah, memiliki karakteristik khusus yang membedakan dari kaidah Akuntansi Konvensional. Kaidah-kaidah Akuntansi Syariah sesuai dengan norma-norma masyarakat islami, dan termasuk disiplin ilmu sosial yang berfungsi sebagai pelayan masyarakat pada tempat penerapan Akuntansi tersebut.

Dari sisi ilmu pengetahuan, Akuntansi adalah ilmu informasi yang mencoba mengkonversi bukti dan data menjadi informasi dengan cara melakukan pengukuran atas berbagai transaksi dan akibatnya yang dikelompokkan dalam account, perkiraan atau pos keuangan seperti aktiva, utang, modal, hasil, biaya, dan laba (Gamal : 2007).

Dalam Al Quran disampaikan bahwa kita harus mengukur secara adil, jangan dilebihkan dan jangan dikurangi. Kita dilarang untuk menuntut keadilan ukuran dan timbangan bagi kita, sedangkan bagi orang lain kita menguranginya. Dalam hal ini, $\mathrm{Al}$ Quran menyatakan dalam berbagai ayat, antara lain dalam surah Asy-Syu'ara ayat 181184 yang berbunyi:"Sempurnakanlah takaran dan janganlah kamu termasuk orang-orang yang merugikan dan timbanglah dengan timbangan yang lurus. Dan janganlah kamu merugikan manusia pada hak-haknya dan janganlah kamu merajalela di muka bumi dengan membuat kerusakan dan bertakwalah kepada Allah yang telah menciptakan kamu dan umat-umat yang dahulu".

Dalam praktiknya, akuntansi syariah lebih banyak berkembang di sektor perbankan. Perkembangan lembaga keuangan syariah di Indonesia cukup pesat terutama perkembangan perbankan syariah dari periode tahun 1998-2000. Hal ini dipengaruhi dengan dikeluarkannya UU No. 10 tahun 1998 yang memberikan landasan hukum lebih kuat untuk perbankan syariah. Selanjutnya dikeluarkan UU No.23 tahun 1999, pemerintah memberikan kewenangan kepada Bank Indonesia untuk dapat menjalankan tugasnya berdasarkan prinsip syariah. Sehingga perkembangan perbankan syariah meningkat tajam terutama dilihat dari peningkatan jumlah bank/kantor yang menggunakan prinsip syariah dan peningkatan jumlah aset yang dikelola. (Nurhayati, 2008)

Bank syariah adalah bank yang beroperasi dengan tidak mengandalkan pada bunga. Dengan kata lain, bank Islam (Bank Syariah) adalah lembaga keuangan yang usaha pokoknya memberikan pembiayaan dan jasa-jasa lain dalam lalu lintas pembayaran serta peredaran uang yang pengoperasiannya di sesuaikan dengan prinsip syariat Islam (Muhammad, 2004).

Perbankan syariah memiliki beberapa skim dan salah satu skimnya adalah pembiayaan murabahah. Menurut PSAK 59 paragraf 52, murabahah adalah akad jual beli barang dengan menyatakan harga perolehan dan keuntungan (margin) yang disepakati oleh penjual dan pembeli.

Ketentuan umum murabahah dalam bank syariah (Nurhayati, 2008):

1. Bank dan nasabah harus melakukan akad murabahah yang bebas riba.

2. Barang yang diperjualbelikan tidak diharamkan oleh syariah Islam. 
3. Bank membiayai sebagian atau seluruh harga pembelian barang yang telah disepakati kualifikasinya.

4. Bank membeli barang yang diperlukan nasabah atas nama bank sendiri, dan pembelian ini harus sah dan bebas riba.

5. Bank harus menyampaikan semua hal yang berkaitan dengan pembelian, misalnya jika pembelian dilakukan secara hutang.

6. Bank kemudian menjual barang tersebut kepada nasabah (pemesan) dengan harga jual senilai harga beli plus keuntungannya. Dalam kaitan ini Bank harus memberitahu secara jujur harga pokok barang kepada nasabah berikut biaya yang diperlukan.

7. Nasabah membayar harga barang yang telah disepakati tersebut pada jangka waktu tertentu yang telah disepaki.

8. Untuk mencegah terjadinya penyalahgunaan atau kerusakan akad tersebut, pihak bank dapat mengadakan perjanjian khusus dengan nasabah.

9. Jika bank hendak mewakilkan kepada nasabah untuk membeli barang dari pihak ketiga, akad jual beli murabahah harus dilakukan setelah barang, secara prinsip menjadi milik bank.

Berdasarkan uraian diatas, maka hipotesis yang dikembangkan oleh penulis adalah :

H1: $\quad$ Biaya overhead berpengaruh terhadap margin pembiayaan murabahah yang ditetapkan oleh PT Bank Muamalat Tbk Cabang Jambi.

H2: Porsi bagi hasil dana pihak ketiga yang dibayarkan oleh bank berpengaruh terhadap margin pembiayaan murabahah yang ditetapkan oleh PT Bank Muamalat Tbk Cabang Jambi.

H3: Tingkat keuntungan yang diinginkan (profit target) berpengaruh terhadap margin pembiayaan murabahah yang ditetapkan oleh PT Bank Muamalat Tbk Cabang Jambi.

H4: Biaya overhead, dana pihak ketiga dan profit target secara simultan berpengaruh terhadap penetapan margin pembiayaan murabahah yang ditetapkan oleh PT Bank Muamalat Tbk Cabang Jambi.

\section{Metode Penelitian}

Objek penelitian ini terdiri dari tiga variabel independen/bebas (X) dan satu variabel dependen/terikat $(\mathrm{Y})$. Variabel independen pada penelitian ini adalah biaya overhead, porsi bagi hasil dana pihak ketiga yang dibayarkan oleh bank, dan tingkat keuntungan yang diinginkan (profit target), sedangkan variabel dependen adalah margin pembiayaan murabahah pemilikan rumah. Sekaran (2003) menyatakan bahwa: " $A$ variable is anything that can take on differing or varying values. The values can differ at various times for the same object or person, or at the same time for different objects or persons". Senada dengan Sekaran, Mudrajad Kuncoro (2003) yang menyatakan bahwa variabel adalah sesuatu yang dapat membedakan nilai atau mengubah nilai. Nilai dapat berbeda pada waktu yang berbeda untuk objek atau orang yang sama, atau nilai dapat berbeda dalam waktu yang sama untuk objek atau orang yang sama. Konsep dapat diubah menjadi variabel dengan cara memusatkan pada aspek tertentu dari variabel itu sendiri.

Agar penelitian ini dapat dilaksanakan sesuai dengan yang diharapkan maka perlu dipahami konsep operasional dan indikator variabel penelitiannya sebagai berikut:

1. Biaya overhead adalah biaya-biaya yang dikeluarkan bank dalam kegiatan penghimpunan dana dari berbagai sumber yang menjadi beban rugi laba.

2. Porsi bagi hasil dana pihak ketiga adalah nilai distribusi bagi hasil bagi pemilik dana pihak ketiga maupun yang berasal dari pinjaman serta ekuitas. 
3. Tingkat keuntungan yang diinginkan (profit target) adalah tingkat keuntungan dari seluruh pembiayaan murabahah yang telah ditargetkan bank.

4. Tingkat margin pembiayaan murabahah adalah selisih antara harga jual dan harga beli yang telah disepakati bersama antara bank dengan debitur pada pembiayaan murabahah.

Jenis data yang digunakan dalam penelitian ini adalah data sekunder yang berasal dari aktivitas murabahah pembiayaan. Sedangkan sumber data diperoleh dari data-data yang dihasilkan PT. Bank Muamalat Indonesia Tbk Cab. Jambi.

Prosedur pengumpulan data adalah suatu usaha sadar untuk mengumpulkan data yang dilakukan secara sistematis dengan prosedur yang telah ditetapkan (Suharsimi Arikunto, 2002). Pengumpulan data dalam penelitian ini dilakukan dengan melakukan observasi dan wawancara terhadap subjek penelitian.

Penelitian ini merupakan jenis penelitian deskriptif-korelasional (kausal) yang akan menjelaskan adakah hubungan dan seberapa besar pengaruh tiap-tiap variabel bebas terhadap variabel terikatnya. Dari penelitian ini diharapkan akan menghasilkan suatu gambaran deskriptif mengenai pengaruh biaya overhead, porsi bagi hasil dana pihak ketiga, dan profit target terhadap penetapan harga jual murabahah dengan spesifikasi model sebagai berikut:

dimana :

$$
Y=\beta_{0}+\beta_{1} X_{1}+\beta_{2} X_{2}+\beta_{3} X_{3}+\varepsilon
$$

$\mathrm{Y} \quad$ : Margin pembiayaan murabahah

$\mathrm{X}_{1} \quad$ : Biaya overhead

$\mathrm{X}_{2} \quad$ : Porsi bagi hasil dana pihak ketiga

X3 : Profit target

$\beta_{0} \quad$ : Konstanta

$\beta_{1}$ : Koefisien regresi variabel $\mathrm{X}_{1}$

$\beta_{2}:$ Koefisien regresi variabel $X_{2}$

$\beta_{3}:$ Koefisien regresi variabel $X_{3}$

$\varepsilon \quad: \quad$ Error term

Model regresi linier berganda dapat disebut sebagai model yang baik jika model tersebut memenuhi asumsi normalitas data dan terbebas dari asumsi-asumsi klasik statistik, baik itu multikolinieritas, autokorelasi, dan heteroskedastisitas.

Proses pengujian asumsi klasik statistik dilakukan bersama-sama dengan proses uji regresi sehingga langkah-langkah yang dilakukan dalam pengujian asumsi klasik statistik menggunakan media kotak kerja yang sama dengan uji regresi SPSS ver.17.

\section{Hasil Penelitian \\ Uji t-Statistik}

Uji t-statistik pada dasarnya bertujuan untuk melihat signifikansi secara parsial dari tiap-tiap variabel independen dalam menerangkan variasi dependen. Hasil perhitungan nilai t-hitung untuk masing-masing variabel bebas dalam model regresi yang diteliti dan hasil keputusan uji parsial diberikan pada tabel berikut : 
Tabel 1Coefficients ${ }^{\mathrm{a}}$

\begin{tabular}{|c|c|c|c|c|c|c|}
\hline \multirow{2}{*}{\multicolumn{2}{|c|}{ Model }} & \multicolumn{2}{|c|}{ Unstandardized Coefficients } & \multirow{2}{*}{$\begin{array}{c}\begin{array}{c}\text { Standardized } \\
\text { Coefficients }\end{array} \\
\text { Beta } \\
\end{array}$} & \multirow[b]{2}{*}{$\mathrm{t}$} & \multirow[b]{2}{*}{ Sig. } \\
\hline & & $\mathrm{B}$ & Std. Error & & & \\
\hline \multirow[t]{4}{*}{1} & (Constant) & 3066882.875 & $1.134 \mathrm{E} 7$ & & .270 & .794 \\
\hline & Biaya Overhead & 8.886 & .774 & .977 & 11.486 & .000 \\
\hline & Bagi Hasil DPK & .067 & .126 & .026 & .535 & .607 \\
\hline & Profit Target & .006 & .148 & .003 & .039 & .970 \\
\hline
\end{tabular}

a. Dependent Variable: Margin Pembiayaan Murabahah

Hasil uji parsial untuk melihat kebermaknaan masing-masing variabel independen dalam model regresi dapat diuraikan sebagai berikut :

a. Pengaruh biaya overhead terhadap margin pembiayaan murabahah

Dari hasil perhitungan diperoleh nilai t-statistik untuk variabel biaya overhead $\left(\mathrm{X}_{1}\right)$ sebesar 11,486 dengan p-value sebesar 0,000. Oleh karena $p$-value lebih kecil dari nilai $\alpha$ yang telah ditetapkan $(0,05)$, maka dapat disimpulkan bahwa secara parsial biaya overhead berpengaruh signifikan terhadap margin pembiayaan murabahah yang ditetapkan PT. Bank Muamalat Tbk Cabang Jambi pada tingkat kepercayaan 95\%.

b. Pengaruh bagi hasil dana pihak ketiga terhadap margin pembiayaan murabahah

Dari hasil perhitungan, diperoleh nilai t-statistik untuk variabel bagi hasil dana pihak ketiga $\left(\mathrm{X}_{2}\right)$ sebesar 0,535 dengan p-value sebesar 0,607. Oleh karena p-value lebih besar dari nilai $\alpha$ yang telah ditetapkan $(0,05)$, maka dapat disimpulkan bahwa secara parsial bagi hasil dana pihak ketiga tidak berpengaruh signifikan terhadap margin pembiayaan murabahah yang ditetapkan PT. Bank Muamalat Tbk Cabang Jambi pada tingkat kepercayaan $95 \%$.

c. Pengaruh profit target terhadap margin pembiayaan murabahah

Dari hasil perhitungan, diperoleh nilai t-statistik untuk variabel profit target $\left(\mathrm{X}_{2}\right)$ sebesar 0,039 dengan $p$-value sebesar 0,970 . Oleh karena $p$-value lebih besar dari nilai $\alpha$ yang telah ditetapkan $(0,05)$, maka dapat disimpulkan bahwa secara parsial profit target tidak berpengaruh signifikan terhadap margin pembiayaan murabahah yang ditetapkan PT. Bank Muamalat Tbk Cabang Jambi pada tingkat kepercayaan 95\%.

\section{Uji F}

Uji Statistik F digunakan untuk mengetahui apakah semua variabel bebas yang terdapat dalam persamaan regresi secara bersama-sama mempengaruhi variabel dependen. Hasil perhitungan nilai $F_{\text {hitung }}$ untuk model regresi yang diteliti dapat dilihat pada tabel berikut :

Tabel 2

ANOVA $^{\text {b }}$

\begin{tabular}{|ll|r|r|r|r|r|}
\hline Model & & Sum of Squares & df & Mean Square & F & Sig. \\
\hline 1 & Regression & $1.591 \mathrm{E} 17$ & 3 & $5.302 \mathrm{E} 16$ & 218.942 & $.000^{2}$ \\
& Residual & $1.937 \mathrm{E} 15$ & & & & \\
& Total & $1.610 \mathrm{E} 17$ & 11 & & & \\
\hline
\end{tabular}

a. Predictors: (Constant), Profit Target, Bagi Hasil DPK, Biaya Overhead

b. Dependent Variable: Margin Pembiayaan Murabahah 
Dari tabel tersebut terlihat bahwa nilai $\mathrm{F}_{\text {hitung }}$ sebesar 218.942 dengan $p$-value sebesar 0,000 . Oleh karena nilai $p$-value lebih kecil dari nilai $\alpha$ yang ditetapkan $(0,05)$, maka dapat disimpulkan bahwa biaya overhead, bagi hasil dana pihak ketiga dan profit target secara simultan berpengaruh signifikan terhadap margin pembiayaan murabahah yang ditetapkan oleh PT. Bank Muamalat Tbk Cabang Jambi dalam laporannya pada tingkat kepercayaan $95 \%$.

\section{Uji Determinasi $\left(R^{2}\right)$}

Menurut Ghozali (2005), Koefisien determinasi $\left(\mathrm{R}^{2}\right)$ pada intinya mengukur seberapa jauh kemampuan model dalam menerangkan variabel dependen. Nilai koefisien determinasi adalah antara nol dan satu. Nilai $R^{2}$ yang kecil berarti kemampuan variabelvariabel dependen sangat terbatas.

Hasil perhitungan secara parsial melalui uji t-statistik dan pengujian secara simultan melalui uji f-statistik menunjukkan adanya pengaruh yang signifikan dari variabel independen terhadap variabel dependen. Adapun besarnya pengaruh biaya overhead, bagi hasil dana pihak ketiga dan profit target terhadap margin pembiayaan murabahah ditunjukkan oleh nilai koefisien determinasi model regresi yang diperoleh. Hasil perhitungan koefisien determinasi diberikan pada tabel berikut :

Tabel 3

\begin{tabular}{|l|r|r|r|r|}
\hline Model & R & R Square & Adjusted R Square & Std. Error of the Estimate \\
\hline 1 & $.994^{\mathrm{a}}$ & .988 & .983 & $1.55611 \mathrm{E} 7$ \\
\hline
\end{tabular}

a. Predictors: (Constant), Profit Target, Bagi Hasil DPK, Biaya Overhead

\section{b. Dependent Variable: Margin Pembiayaan Murabahah}

Pada tabel di atas terlihat nilai koefisien determinasi Adjusted $R$ Square sebesar 0.983 , hal ini berarti $98,3 \%$ margin pembiayaan dapat dijelaskan oleh tiga variabel independen yaitu biaya overhead, bagi hasil dana pihak ketiga dan profit target. Sedangkan 1,7\% lainnya dipengaruhi faktor lain yang tidak diteliti dalam penelitian ini.

Tabel 4

Coefficients $^{\mathrm{a}}$

\begin{tabular}{|c|c|c|c|c|}
\hline & & \multicolumn{3}{|c|}{ Correlations } \\
\hline \multicolumn{2}{|c|}{ Model } & Zero-order & Partial & Part \\
\hline \multirow[t]{3}{*}{1} & Biaya Overhead & .994 & .971 & .445 \\
\hline & Bagi Hasil DPK & .573 & .186 & .021 \\
\hline & Profit Target & .852 & .014 & .002 \\
\hline
\end{tabular}

a. Dependent Variable: Margin Pembiayaan Murabahah

Adapun besar pengaruh masing-masing variabel independen dalam model regresi dapat dilihat dari korelasi parsial. Hasil perhitungan koefisien korelasi parsial untuk masing-masing variabel yang terlihat pada tabel 8 diatas menunjukkan bahwa biaya overhead memiliki pengaruh terbesar terhadap margin pembiayaan murabahah dibandingkan dengan bagi hasil dana pihak ketiga dan profit target yang ditetapkan oleh PT. Bank Muamalat Tbk Cabang Jambi. 
Pengaruh biaya overhead terhadap margin pembiayaan murabahah pada PT. Bank Muamalat Tbk Cabang Jambi.

Hasil penelitian menunjukkan biaya overhead berpengaruh signifikan terhadap margin pembiayaan murabahah yang ditetapkan oleh PT. Bank Muamalat Tbk Cabang Jambi. Hal ini terlihat pada tabel 5 output SPSS yang mana variabel biaya overhead $\left(\mathrm{X}_{1}\right)$ sebesar 11,486 dengan $p$-value sebesar 0,000 . Oleh karena $p$-value lebih kecil dari nilai $\alpha$ yang telah ditetapkan $(0,05)$, dan dapat disimpulkan biaya overhead berpengaruh signifikan terhadap margin pembiayaan murabahah.

Hasil penelitian ini selaras dengan penelitian Heykal (2005) dan Asmita (2004) yang menunjukkan bahwa seluruh biaya yang dikeluarkan dan dibebankan kedalam transaksi, digunakan untuk kegiatan operasional baik langsung maupun tidak langsung, digolongkan sebagai biaya overhead.

Pengaruh bagi hasil dana pihak ketiga terhadap margin pembiayaan murabahah pada PT. Bank Muamalat Tbk Cabang Jambi.

Hasil penelitian menunjukkan bagi hasil dana pihak ketiga tidak berpengaruh signifikan terhadap margin pembiayaan murabahah yang ditetapkan oleh PT. Bank Muamalat Tbk Cabang Jambi. Dari hasil perhitungan, diperoleh nilai t-statistik untuk variabel bagi hasil dana pihak ketiga $\left(\mathrm{X}_{2}\right)$ sebesar 0,535 dengan p-value sebesar 0,607. Oleh karena $p$-value lebih besar dari nilai $\alpha$ yang telah ditetapkan $(0,05)$, dengan demikian bagi hasil dana pihak ketiga tidak berpengaruh terhadap margin pembiayaan yang ditetapkan oleh PT. Bank Muamalat Tbk Cabang Jambi.

Hasil penelitian ini berbeda dari penelitian sebelumnya yang mana pada penelitian terdahulu bagi hasil dana pihak ketiga mempunyai pengaruh pada margin pembiayaan murabahah. Hal ini mungkin diakibatkan periode penelitian ini yang lebih pendek daripada penelitian-penelitian sebelumnya.

Pengaruh profit target terhadap margin pembiayaan murabahah pada PT. Bank muamalat Tbk Cabang Jambi.

Hasil penelitian menunjukkan profit target tidak berpengaruh signifikan terhadap margin pembiayaan murabahah yang ditetapkan oleh PT. Bank Muamalat Tbk Cabang Jambi. Haal ini ditunjukkan dari hasil perhitungan uji t-statistik untuk variabel profit target $\left(\mathrm{X}_{2}\right)$ sebesar 0,039 dengan p-value sebesar 0,970. Oleh karena $p$-value lebih besar dari nilai $\alpha$ yang telah ditetapkan $(0,05)$, maka dapat disimpulkan bahwa secara parsial profit target tidak berpengaruh signifikan terhadap margin pembiayaan murabahah yang ditetapkan PT. Bank Muamalat Tbk Cabang Jambi.

Hasil penelitian ini senada dengan penelitian Mohamad Heykal (2005) yang menunjukkan pengaruh profit target tidak signifikan terhadap margin pembiayaan murabahah pada Bank Syariah.

\section{Simpulan}

1. Secara parsial pengaruh biaya overhead, bagi hasil dana pihak ketiga dan profit target terhadap margin pembiayaan murabahah yang ditetapkan oleh PT. Bank Muamalat Tbk Cabang Jambi menunjukkan hal-hal sebagai berikut :

a. Biaya overhead berpengaruh signifikan terhadap margin pembiayaan murabahah yang ditetapkan oleh PT. Bank Muamalat Tbk Cabang Jambi

b. Bagi hasil dana pihak ketiga tidak berpengaruh signifikan terhadap margin pembiayaan murabahah yang ditetapkan oleh PT. Bank Muamalat Tbk Cabang Jambi

c. Profit target tidak berpengaruh signifikan terhadap margin pembiayaan murabahah yang ditetapkan oleh PT. Bank Muamalat Tbk Cabang Jambi 
2. Secara simultan biaya overhead, bagi hasil dana pihak ketiga dan profit target secara simultan berpengaruh terhadap margin pembiayaan murabahab yang ditetapkan oleh PT. Bank Muamalat Tbk Cabang Jambi.

3. Dari hasil penelitian diketahui variabel independen yang paling dominan berpengaruh terhadap margin pembiayaan murabahah adalah biaya overhead.

\section{Saran}

1. Sebaiknya peneliti selanjutnya melakukan penelitian dengan periode waktu yang lebih panjang, sehingga data-data yang digunakan lebih akurat dan relevan untuk menentukan margin pembiayaan murabahah.

2. Sebaiknya peneliti selanjutnya menambahkan faktor-faktor lain diluar variabel yang diteliti, seperti volume pembiayaan murabahah dan tingkat suku bunga bank konvensional.

\section{Keterbatasan Penelitian}

1. Penelitian ini hanya terbatas satu tahun, mengingat keterbatasan data yang diperoleh dari PT. Bank Muamalat Tbk Cabang Jambi, yang pada penelitian sebelumnya dilakukan pada PT. Bank Muamalat Indonesia.

2. Faktor-faktor eksternal diluar variabel yang diteliti tidak dapat diidentifikasi karena singkatnya waktu penelitian.

\section{Daftar Pustaka}

Akhmadi, Slamet (2004), Evaluasi Kredit Kepemilikan Rumah Dalam Bank Syariah, Makalah pada Simposium Nasional Sistem Ekonomi Islami II, Malang.

Alkaaf, Abdullah Zaki (2002), Ekonomi dalam Perspektif Islam, Bandung : cetakan pertama pustaka setia

Arifin Badri, Muhammad (2008), Tinjauan Kritis Perbankan Syariah, Jakarta, Pustaka Ibn Umar

Ascarya, (2007), Akad dan Produk Bank Syariah, Jakarta, PT Raja Grafindo

Arifin Zainul (2005), Dasar-dasar Manajemen Bank Syariah, Jakarta : alvabet

Asmita, Budi, SE, Msi, 2004, Analisis Faktor Yang Mempengaruhi Margin Pembiayaan Murabahah, Studi Kasus Pada BPRS PNM Mentari, Universitas Indonesia, Jakarta

DSN MUI, Himpunan Fatwa Dewan Syariah Nasional, Edisi III, Jakarta, 2006

Ghozali, Imam.2005. Aplikasi Analisis Multivariate dengan Program SPSS. Semarang. Badan Penerbit Universitas Diponegoro

Gujarati, Damodar. 2003. Basic Econometrics $4^{\text {th }}$ International Edition. Mc. Graw Hill. USA

Hadi Muttaqin Hasyim (2009), http://wordpress.com/akuntansi-islam-syariah

Hakim, Abdul (2002), Statistik Indukti untuk Ekonomi dan Bisnis, Ekonisia, Yogyakarta

Heri Sudarsono. (2003), Bank dan Lembaga Keuangan Syariah, UII Press

Ifham, Ahmad. 2006. Strategi Bank Syariah Merebut Hati Nasabah.

Ikatan Akuntan Indonesia (IAI). 2004. PSAK no 31: Akuntansi Perbankan (Revisi 2000). Jakarta: Penerbit Salemba Empat. Salemba Empat. 2004. PSAK no 59: Akuntansi Perbankan Syariah. Jakarta: Penerbit

Kamayanti \& Parwita Setya W. 2008. Persepsi Nasabah dalam Memilih Bank Syariah dan Bank Konvensional di Sidoarjo. Melalui http://akuntansisyariah.multiply.com

Karim, Adiwarman (2003). Bank Islam Analisis Fiqih dan Keuangan.

Maghfirah, Ester Dwi (2005), Prospek Perbankan Syariah Pasca Fatwa MUI, diambil 20 April 2005, dari http//:www.solusihukum.com 
Merza, Gamal (2007), http://aharlibrary.wordpress.com/2007/03/15/mengenal-prinsipakuntansi-syariah/

Mohamad Heykal, SE, Msi, 2005, Analisa faktor-faktor yang mempengaruhi margin murabahah pembiayaan murabahah, studi kasus pada PT Bank Muamalat Indonesia Tbk, Universitas Indonesia, Jakarta

Muhammad Akram Khan (2004), Manajemen Dana Bank Syariah, Ekonisia,

Yogyakarta.

Muhammad Syafi’i Antonio (2001). Bank Syariah dari teori ke praktek, Jakarta : Gema Insani

Kamayanti, Ari \& Parwita Setya Melalui http://akuntansisyariah.multiply.com

Saleh, Rachmaf. 2004. Studi Empiris Ketepatan Waktu Pelaporan Keuangan Perusahaan Manufaktur di Bursa Efek Jakarta. Simposium Nasional Akuntansi VIII, Denapasar

Sekaran, Uma. 2003. Research Methods For Business: A Skill-Building Approach. $3^{\text {rd }}$

Edition. New York : John Wiley \& Sons Inc.

Slamet Wiyono, (2005), Akuntansi Perbankan Syariah, Jakarta : PT. Grasindo

Sri Nurhayati, (2008), Akuntansi Syariah di Indonesia, Salemba Empat, Jakarta

Syahyuti. 2005. Review dari Sepuluh Penelitian tentang Perbankan Syariah. Melalui http:www. solusihukum.com

Usman Rachmadi, SH. 2002. Aspek-aspek hukum Perbankan Islam, PT Citra Adiyta Bakti, Bandung

Winwin Yadiati \& Ilham Wahyudi. 2006.Pengantar Akuntansi, Jakarta: Kencana.

Y. Sri Susilo, dkk (2000). Bank \& Lembaga Keuangan Lain, Salemba Empat, Jakarta.

Zulfikar Nazara, (2007), Perkembangan Bank Syariah. Makalah dalam Seminar Nasional dan Launching Jurnal LEBI 2007, Yogyakarta, 17 Desember 2007

Zulkifli, Sunarto, 2003, Panduan Praktis Transaksi Perbankan Syariah, Zikrul Hakim, Jakarta 